e- Jurnal Universitas Pendidikan Ganesha

Pendidikan Geografi

\title{
TINJAUAN GEOGRAFI PENDUDUK TENTANG SEBARAN SAPSIAL DAN KARAKTERISTIK MIGRAN ASAL PULAU JAWA DI KOTA SINGARAJA
}

\author{
Nida Anggraeni, Ida Bagus Made Astawa, I Made Sarmita \\ Program Studi Pendidikan Geografi \\ Universitas Pendidikan Ghanesa \\ Singaraja, Indonesia \\ e-mail: \{anggranida@yahoo.com, idabagusmadeastawa@yahoo.com, \\ madesarmita@gmail.com \\ @undiksha.ac.id
}

\begin{abstract}
Abstrak
Penelitian ini ini dilaksanakan di Kota Singaraja dengan tujuan: (1). Menganalisis sebaran spasial migran asal pulau Jawa pada masing-masing kelurahan di kota Singaraja, (2). Menganalisis karakteristik migran asal Jawa pada masing-masing kelurahan di kota Singaraja, (3). Menganalisis faktor pendorong dan faktor penarik migran asal Jawa bermigrasi ke kota Singaraja. Penelitian ini dirancang sebagai penelitian deskriptif. Sampel ditentukan melalui dua tahap yaitu sampel wilayah sebanyak 3 kelurahan (Banyuasri, kaliuntu, Kampung Bugis) adi 19 kelurahan secara "purposif", sedangkan setelah sampel wilayah ditentukan maka subyek sampling ditentukan secara "porposrional random sampling", yaitu sebesar 15\% (55 orang) dari keseluruhan populasi sebanyak 364 yang tersebar pada 3 kelurahan. Pengumpulan data primer menggunakan pencatatan dokumen, yang selanjutnya dianalisis secara deskriptif kulaitatif dengan menggunakan pendekatan keruangan.

Hasil penelitian menunjukkan bahwa: (1). Sebaran migran asal Jawa di kota Singaraja terkonsentrasi di kelurahan Banyuasri dari 3 kelurahan utamanya (Banyuasri, Kaliuntu, dan Kampung Bugis). Hal tersebut sangat terkait dengan nilai kefaedahan daerah dilihat dari aksesibilitas, peluang kerja, kemanan, dan kenyamanan. (2). Ketiga kelurahan sebagai tempat migran tersebar di kota Singarja memiliki karakteristik migran yang relatif sama yaitu penduduk usia produktif dan jenis kelamin migran yang didominasi oleh jenis kelamin laki-laki $(56,36 \%)$, berpendapatan rendah $(60 \%)$, dan bekerja sebagai pedagang $(43,63 \%)$. (3). Faktor-faktor yang mempengrauhi migran asa Jawa bermigrasi ke kota Singaraja disebabkan oleh sempitnya peluang kerja di daerah asal (faktor pendorong), dan tersedianya lapangan kerja di daerah tujuan (faktor pendorong).
\end{abstract}

Keywords: Sebaran spasial, karakteristik, faktor pendorong, faktor penarik, migran asal Jawa 


\title{
TINJAUAN GEOGRAFI PENDUDUK TENTANG SEBARAN SPASIAL DAN KARAKTERISTIK MIGRAN ASAL PULAU JAWA DI KOTA SINGARAJA
}

\author{
Nida Anggraeni, Ida Bagus Made Astawa, I Made Sarmita \\ Geography Education Departement, \\ Ganesha University of Education \\ Singaraja, Indonesia \\ e-mail: \{nida_anggraeni@yahoo.com, idabagusmadeastawa@yahoo.com, \\ madesarmita@gmail.com \\ $@$ undiksha.ac.id
}

\begin{abstract}
Abstrack
This research was conducted in Singaraja with the purpose are to (1) Analyze the spatial; distribution of migrants coming from Java to Singaraja in the each villages. (2) Analyze the cakteristic of migrants coming from Java to Singaraja in the each villages. (3) Analyze the driving factor and the reason the migrants coming from Java to Singaraja. this study was designed as a descriptive research. The sample is determined by two stages, namely, the sample area as much as 3 villages (Banyuasri, Kalintu, Kampung Bugis) from 19 villages in "pupososif" while after the sample areas of the subject then please specify the sampling in specified in "proportional random sampling" tecnicque which amount 15\% (55 people) of the total population that as many as 384 people who spread over 3 villages. The primary data was collected by method of observation and interviews which secondary data wa collected by qualitative description method with using spatial approachment of geography.

The result of the research showed that (1) distribution of migrant origin from Java City of Singaraja are conentraced in the village Banyuasri of the 3 main villages (Banyuasri,Kaliuntu, and Kampung Bugis). It is so associated with the value to the cheerfulness of the areas as seen from job opportunities, accessibility, security, and confort. (2) The third neighborhood as a place of migrant scattered in the city of Singaraja route has the characteristic of migrants realitively the same, namely the prodictive age population and gender migrants dominated by gender male (56.36\%), low-income $(60 \%)$, and worked as a merchant (43.63\%). (3) The factor that affect migrant Javanese origin migrated to the city Singaraja was caused by the narrowness of job opportunities in the area of origin (push factor), and the availability of employment opportunities the area of destination (pull factor).
\end{abstract}

Keywords: Spatial Distribution, characteristics, the driving factor, factor in towing, migrant origin of Java 


\section{PENDAHULUAN}

Geografi penduduk pada hakikatnya mempelajari penduduk dalam kaitannya dengan ruang huni manusia. Tekanan yang diberikan geografi penduduk dalam mempelajari penduduk terletak pada struktur dan proses penduduk yang hubungannya dengan ruang. Peranan sosial, ekonomi, dan lingkungan dipandang sebagai komponen ruang yang berdampak pada kependudukan suatu wilayah.

Kawi (2005:7) menyatakan bahwa "geografi penduduk adalah suatu studi tentang penduduk dan bumi sebagai tempat kehidupannya, jumlah, karakteristik, dan dinamika dalam kaitannya dengan sosial, ekonomi, dan lingkungan, dengan menggunakan pendekatan ekologi". Penduduk dalam studi geografi penduduk akan dilihat dalam kaitannya dengan sosial, ekonomi, dan lingkungan serta dinamika penduduk yang meliputi fertilitas, mortalitas, migrasi dan pertumbuhannya dalam satu ruang.

Mobilitas penduduk adalah salah satu variabel pokok demografi yang dikaji dalam Geografi Penduduk. Mobilitas penduduk yang bersifat permanen sangat berperan dalam proses pertumbuhan penduduk di kota. Hal tersebut dilihat dari perkembangan tren jangka panjang yang terjadi, bahwa kebanyakan daerah alternatif yang menjadi perluasan kesempatan kerja cenderung terkonsentrasi di daerah perkotaan. Seiring dengan peningkatan pendidikan sumbedaya manusia di daerah pedesaan, memperoleh keterampilan yang diperlukan yang tidak berkaitan dengan pertanian, sehingga terjadi arus migrsi dari desa ke kota.

Migrasi desa-kota adalah salah satu kajian dalam geografi penduduk. Terjadinya migrasi-desa kota di Indonesia lebih disebabkan oleh adanya ketimpangan pembangunan yang terjadi antara desa dan kota. Pertumbuhan penduduk di daerah pedesaan pada satu sisi dan pembangunan yang cenderung terkonsentrasi di perkotaan mendorong masyarakat untuk bermobilitas menuju ke kota. Ketimpangan antar desa-kota banyak memunculkan mobilitas penduduk dari desa ke kota. Ketimpangan antar satu daerah dengan daerah yang lain akan berdampak pada semakin padatnya penduduk di daerah yang dianggap sudah mengalami perkembangan.

Hal itu didukung oleh Gilbert dan Gugler (1996:53) yang mengemukakan bahwa pembangunan di perkotaan sepertinya mendapatkan prioritas yang kemudian melahirkan "urban bias". Istilah urban bias ini dimaksudkan untuk melukiskan pembangunan yang lebih menitik beratkan pada pembangunan kota dibandingkan desa. Hal tersebut melahirkan pandangan bahwa semakin terbukanya kesempatan kerja di perkotaan. Urban bias dapat diartikan sebagai kesenjangan antara perkotaan dan pedesaan yang berdampak pada semakin meluasnya migrasi dari pedesaan. Selain itu, di pedesaan yang bercorak agraris juga mengalami perubahan fungsi lahan karena semakin menyempitnya lahan yang diolah petani. Berkurangnya lahan yang diolah dan menyempitnya lahan yang diolah menyebabkan sebagian penduduk beralih ke sektor non pertanian. Bagi yang tidak memiliki kemampuan di sektor non pertanian di desanya, akan terdorong untuk pindah ke kota yang memunculkan urbanisasi.

Urban bias juga terlihat di Bali yang memprioritaskan pembangunan di daerah 
perkotaan dibanding di daerah pedesaan. Bali juga telah berkembang sebagai daerah pariwisata, sehingga menjadikan daerahdaerahnya berpotensi tinggi dalam mengembangkan peluang kerja. Peluang kerja yang tinggi menjadikan daerah-daerah di Bali memiliki daya tarik bagi para calon migran sebagai daerah tujuan, sehingga akan mendorong masyarakat desa untuk berpindah ke kota. Dampak migrasi desa-kota tidak lepas dari masalah migrasi pada umumnya, yaitu masalah sosial, ekonomi, dan lingkungan, baik di kota maupun di desa.

Singaraja adalah salah satu kota yang tidak lepas dari fenomena migrasi desa-kota. Kota Singaraja telah tumbuh sebagai kota dengan heterogenitasnya yang cukup tinggi. Selain itu Singaraja merupakan kota pendidikan. Pertumbuhan kota Singaraja sebagai kota pendidikan memiliki pengaruh terhadap migran masuk. Hal ini disebabkan pembangunan kota dan laju pertumbuhan perekonomian yang dinilai mengalami perkembangan. Salah satunya penunjang kota pendidikan adalah berdirinya sejumlah lembaga pendidikan tinggi di kota Singaraja. Hal ini dapat memberikan dampak positif terhadap kondisi sosial ekonomi masyarakat. Kenyataan inilah yang kemudian menjadi fenomena yang menarik para calon migran dari luar Bali untuk menetap di kota Singaraja.

Migran yang bermigrasi ke kota Singaraja berasal dari berbagai daerah di Indonesia. Salah satunya adalah migran asal jawa. Keberadaan para migran asal Jawa di kota Singaraja sendiri tidak lepas dari informasi tentang potensi daerah tujuan, disamping jarak yang terkonektivitas antara Jawa-Bali. Informasi tentang daerah tujuan tersebut tentu didapat oleh para calon migran dari berbagai sumber. Pada umumya informasi tersebut berasal dari para sanak saudara dan kerabat yang sudah di kenal para calon migran. Informasi pada dasarnya berkaitan dengan kegiatan ekonomi yang akan dapat di lakukan di daerah tujuan migrasi, dan kehidupan di daerah tujuan. Informasi daerah tujuan yang berkaitan dengan peluang usaha yang menjanjikan (kegiatan ekonomi) adalah menjadi salah satu faktor penarik bagi calon migran asal Jawa untuk bermigrasi ke kota Singaraja.

Hal ini sejalan dengan yang dikemukakan oleh Mantra (2003: 58) bahwa motivasi utama yang melatar belakangi perpindahan dari daerah asal ke daerah tujuan adalah motif ekonomi. Motif ini berkembang karena adanya ketimpangan ekonomi antar daerah asal dan daerah tujuan. Kondisi paling dirasakan menjadi pertimbangan rasional yang menyebabkan individu melakukan mobilitas ke kota besar adalah adanya harapan untuk memperoleh pekerjaan dan pendapatan yang lebih tinggi dari pada yang diperoleh di tempat asalnya.

Tingkat gaji atau upah antara kota dan desa akan mendorong penduduk desa untuk bermigrasi ke kota, guna mencukupi kebutuhan yang semakin beragam. Penduduk baru akan memutuskan melakukan migrasi jika penghasilan bersih di kota dinilai melebihi penghasilan bersih yang tersedia di desa. Selain itu terdapat hubungan yang jelas antara tingkat pendidikan yang dicapai dengan keinginan untuk bermigrasi. Orang yang berpendidikan tinggi cenderung lebih banyak melakukan migrasi dari pada yang pendidikannya lebih rendah. Peluang dari kesempatan kerja di desa yang tidak menunjang bagi mereka yang berpendidikan. Hal ini mendorong meningkatkan arus migrasi desa ke kota.

Lee (dalam Mantra, 2003:57) menyatakan bahwa upaya untuk melakukan kegiatan migrasi tidak lepas dari jarak, yang dalam geografi penduduk merupakan faktor utama alasan bagi migran untuk melakukan mobilitas dan masuk ke suatu wilayah. Jarak yang relatif dekat adalah salah satu penyebab terjadinya migrasi penduduk. Sudah tentu faktor 
jarak ini tidak berdiri sendri karena dipengaruhi oleh kondisi sosial ekonomi migran. Selain itu aksesibilitas sarana dan prasarana transportasi yang memadai akan memperlancar terjadinya mobilitas penduduk antar daerah, antar provinsi maupun antar kota. Sarana seperti transportasi penyebrangan yang menghubungan antar pulau yang tersedia 24 Jam adalah salah satu faktor yang dapat mendukung migrasi antar pulau meningkat. Hal ini dinilai yang menjadi alasan migran asal Jawa untuk melakukan migrasi dari daerah asal ke daerah tujuan.

Masuknya para migran ke kota Singaraja dinilai merupakan adanya keinginan migran sendiri terhadap daerah tujuan. Kota Singaraja dalam hal ini diyakini mempunyai peluang besar oleh para migran asal Jawa. Masing-masing migran asal Jawa yang datang ke Kota Singaraja memiliki latar belakang daerah asal yang berbeda-beda, baik dilihat dari desa, kecamatan, kabupaten maupun provinsi. Perbedaan daerah asal para migran itu dapat memunculkan konflik apabila tidak terdapat harmonisasi yang mengatur kehidupan bermasyarakat.

Migran asal Jawa yang datang ke kota Singaraja akan memberikan pengaruh besar terhadap komposisi penduduk kota Singaraja. Hal ini akan memunculkan peningkatan kebutuhan lahan, terutama untuk permukiman para migran yang tinggal di kota singaraja. Selain itu sebagai akibat adanya migrasi di kota Singaraja berbagai hal dapat terjadi seperti terjadi kemacetan lalu lintas karena semakin bertambahnya pengguna kendaraan. Kepadatan permukiman yang ada di kota Singaraja juga terlihat padat, karena kebutuhan penduduk akan tempat tinggal serta untuk menunjang aktivitas ekonomi. Hal ini menyebabkan alih fungsi lahan semakin meluas. Migran yang datang ke kota Singaraja juga meyakini bahwa mereka akan mendapatkan penghidupan yang lebih layak di daerah tujuan dari pada di daerah asalnya, hal ini dapat meningkatan jumlah tenaga kerja yang ada di kota Singaraja, namun tidak semua migran memiliki skill dan pendidikan yang baik. Berkenaan dengan peningkatan jumlah tenga kerja yang disebabkan para migran dapat menyebabkan meningkatnya pengangguran di kota Singaraja.

Berdasarkan uraian tersebut, pengungkapan tentang migran asal Jawa di daerah tujuan migrasi penting untuk ditinjau lebih fokus, karena permasalahan fenomena sosial ekonomi yang muncul di daerah tujuan migran dapat memunculkan implikasi yang luas. Oleh sebab itu penelitan dilakukan untuk mengidentifikasi faktor-faktor penyebab terjadinya migrasi, karaktersistik serta persebaran migran yang ada di kota Singaraja, dalam suatu penelitian yang berjudul "Tinjauan Geografi Penduduk Tentang Sebaran Spasial Dan Karakteristik Migran Asal Jawa Di Kota Singaraja”.

\section{METODE PENELITIAN}

Penelitian ini dirancang sebagai penelitian deskripstif. Sampel ditentukan melalui dua tahap yaitu, sampel wilayah sebanyak 3 kelurahan (Banyuasri, Kaliuntu dan Kampung Bugis) dari 19 kelurahan secara "purposif", sedangkan setelah sampel wilayah di tentukan maka subyek sampling yang ditentukan secara "proporsional random sampling", yaitu sebesar 15\% (55 orang) dari kelseluruhan populasi sebanyak 364 yang tersebar di tiga Desa/Kelurahan. Pengumpulan data primer menggunakan metode observasi dan wawancara, serta data sekunder menggunakan pencatatan dokumen, yang selanjutnya dianalisis secara deskriptif kualitatif dengan menggunakan pendekatan keruangan.

\section{HASIL DAN PEMBAHASAN}


Untuk mendapatakan data yang lebih rinci tentang sebaran spasial dan karakteristik migran asal pulau Jawa di Kota Singaraja. Hasil penelitian yang dilakukan di ketiga kelurahan di kota Singaraja yaitu:

\section{Sebaran Migran Asal Pulau Jawa Di Kota Singaraja}

Berdasarkan hasil penelitian yang dilakukan pada masing-masing kelurahan di Kota Singaraja terdapat 3 kelurahan yang dijadikan migran asal pulau Jawa sebagai tempat tinggal daerah tujuan yaitu (kelurahan Banyuasri, Kaliuntu, Kampung Bugis) melihat adanya catatan migran asal Pulau Jawa di masingmasing kelurahan di Kota Singaraja tersebar berada di ketiga kelurahan tersebut.

Para migran pada umumnya memilih daerah tujuan migrasi ialah di wilayah kota, karena kota dianggap sebagai daerah yang mempunyai ekonomi tinggi. Selain itu Kota Singaraja memiliki peluang besar bagi para migran asal Jawa untuk dijadikan daerah tujuan untuk bermigrasi. Selain itu migran menyebar pada daerah-daerah yang diniliai memiliki ke faedahan yang tinggi terutama terkait dengan aksesibilitas dan peluang kerja, di samping keamanan dan kenyamanan. Berdasarkan penelitian yang telah dilakukan di tiga kelurahan di Kota Singaraja, dilihat bahwa sebaran migran asal Jawa lebih dominan di kelurahan Banyuasri, hal tersebut dilihat dari catatan administrasi pada masing-masing kelurahan.

Sebaran migran asal Jawa di kota Singraja tergolong merata, tidak adanya pengelompokan yang signifikan terhadap hunian atau tempat tinggal para migran, karena pada umumnya wilayah kota Singaraja memiliki peluang yang cukup tinggi bagi para migran asal Jawa dan memiliki potensi yang baik. Oleh sebab itu, wilayah atau daerah yang ditempati oleh para migran berpotensi untuk dijadikan kegiatan ekonomi seperti usaha dagang dan lain sebagainya.

\section{Karakteristik Migran Asal Jawa di Kota Singaraja}

Karakteristik migran pada umumnya dapat dilihat dari 3 hal, yaitu karakteristik demografi, karakteristik sosial, dan karakteristik ekonomi. Hal tersebut selalu ada bagi para migran yang dianggap sebagai ciri khas atau karakteristik seseorang atau kelompok dalam melakukan migrasi. Karakteristik demografi para migran lebih dominan dilakukan oleh laki-laki dari pada perempuan, dengan usia produktif 15-64 tahun yang di dominasi oleh usia 24-29 tahun. Dilihat dari karakteristik sosial para migran asal Jawa dapat dijelaskan bahwa pada umumya para migran tersebut, dilihat dari status sosialnya tidak memiliki kedudukan di daerah asal, sedangkan penduduk di negara-negara berkembang memilki pendidikan yang rendah. Untuk karakteristik ekonomi para migran umumya adalah mereka yang memiliki perekonomian yang rendah dan ingin mendapatkan pekerjaan yang lebih baik dari pada di daerah asal.

Dalam jurnal hasil penelitian yang dilakukan oleh Siska (Jurnal, 2013), yakni mengenai karakteristik migran pada umumnya dapat dilihat dari 3 hal yaitu karakteristik demografi, karakteristik sosial, dan karakteristik ekonomi. Karakteristik demografi para mgran tersebut dapat dilihat dari segi umur dan jenis kelamin. Untuk karakteristik sosial migran dilihat dari tingkat pendidikan terakhir yang ditempuh, bahwa tingkat pendidikan ini sangat berpengaruh terhadap keadaan sosial migran itu sendiri, sedangkan untuk karakteristik ekonomi migran dapat dilihat dari pekerjaan migran dan pendapatan migran di daerah asal.

Penelitian sejenis juga telah dilakukan oleh Sudibia (Jurnal 2012) mengenai pola migrasi dan karakteristik migran berdasarkan sensus penduduk di provinsi Bali 2010 menunjukkan 
hasil yang diperoleh yaitu bahwa karakteristik migran risen yang dapat dibahas adalah mengenai umur, pekerjaan, tingkat pendidikan, status kawin, status pekerjaan dan lapangan pekerjaan.

Mengacu pada pendapat dan hasil penelitian di atas, bahwa berdasarkan hasil penelitian yang didapat di kota Singaraja yakni desa/kelurahan Banyuasri, Kaliuntu, dan Kampung Bugis karakteristik para migran dapat dijelaskan seperti berikut.

Dari segi demografi para migran asal Jawa di kota Singaraja adalah berada pada usia produktif. Usia migran terendah adalah 18 tahun dan tertinggi adalah 49 tahun. Dominan para migran dilihat dari segi umur adalah 25-29 tahun. Hal tersebut sesuai dengan apa yang diungkapkan oleh Here (dalam Mantra, 2003:157) karena pada kenyataannya individu yang melakukan migrasi ke daerah tujuan adalah individu yang memiliki tanah sempit dan kebanyakan laki-laki dewasa dengan unur masih tergolong muda yang berkisar antara (20-35 tahun).

Berdasarkan jenis kelamin menunjukkan bahwa laki-laki yang lebih dominan dibandingkan dengan perempuan. Dalam hal ini memperlihatkan bahwa laki-laki memiliki sebuah tanggung jawab besar terhadap kelangsungan kehidupan keluarganya. Hak tersebut sesuai dengan apa yang dikemukakan oleh Here (dalam Mantra 2003, bahwa kebanyakan individu yang bermigrasi adalah laki-laki dewasa yang memiliki tanah sempit tidak memiliki kedudukan kepemimpinan di daerah asalnya. Untuk kota Singaraja sendiri migran laki-laki lebih banyak melakukan migrasi dari pada perempuan, karena laki-laki lebih besar tuntutan tanggung jawab dalam menghidupi keluarga.

Status kawin para migran asal Jawa di kota Singaraja terdapat migran yang sudah kawin, belum kawin, janda dan duda. Untuk status kawin para migran asal Jawa di kota Singaraja lebih banyak didominasi oleh migran yang sudah kawin dari pada yang belum kawin. Hal ini juga terlihat pada masing-masing kelurahan. Status migran yang sudah kawin paling banyak terdapat di kelurahan Kampung Bugis. Selain status penduduk yang sudah kawin, status migran yang belum kawin yang lebih dominan terdapat di kelurahan Banyuasri sedangkan status janda maupun duda paling banyak di dominasi oleh migran kelurahan Kaliuntu.

Dominannya para migran yang berstatus kawin memperlihatkan tanggung jawab sebagai suami-istri dalam menghidupi rumah tangga mengharuskan mereka untuk bekerja. Tidak adanya pekerjaan yang sesuai dengan keterampilan yang mereka miliki di daerah asal atau rendahnya pendapatan di daerah asal menyebabkan mereka melakukan mobilitas dan menetap di kota Singaraja setelah mendapatkan pekerjaan yang layak.

Karakteristik sosial migran dapat diketahui dengan melihat tingkat pendidikan mereka. Untuk kota Singaraja sendiri tingkat pendidikan para migran paling banyak tamat pada tingkat SMP. Hal ini terlihat pada masing-masing desa/kelurahan di kota Singaraja tingkat pendidikan terakhir yang ditempuh oleh para migran asal Jawa paling banyak ditamatkan tingkat SMP. Selain itu migran yang tamat pada jenjang SMA ke atas juga yang cukup banyak, hal ini menunjukkan bahwa tingkat pendidikan migran asal Jawa tergolong cukup baik. Karena sulitnya mendapatkan pekerjaan di daerah asal, maka para migran lebih memilih untuk melakukan migrasi, dengan harapan mendapatkan pekerjaan dan pendapatan yang lebih baik.

Jika dilihat dari karakteristik ekonomi migran asal Jawa dapat dilihat pula dengan melihat pekerjaannya. Sebagian besar migran asal Jawa bekerja sebagai pedagang, dan hanya sebagian kecil sebagai buruh dan kaaryawan swasta. Rendahnya tingkat pendidikan diduga sebagai faktor dominan yang menyebabkan 
migran di Kota Singaraja memilih jenis pekerjaan sebagai pedagang. Hal tersebut sesuai dengan apa yang dikemukakan oleh Mantara 2003 bahwa sebagian besar yang bermigrasi ke daerah tujuan bekerja sebagai buruh, pedagang yang cenderung terdorong bermigrasi ke kota. Dilihat dari per kelurahan proporsi migran asal jawa terbesar yang memilih sebagai pedagang terdapat di kelurahan Banyuasri dan Kampung Bugis dan yang terendah di kelurahan Kaliuntu. Selain itu, terdapat pula sebagian besar migran khususya perempuan yang sudah menikah memilih untuk menetap di rumah dan menjadi ibu rumah tangga.

Selain dilihat dilihat dari jenis pekerjaan migran, dapat pula dilihat dari segi ekonomi, yaitu pendapatan para migran asal Jawa setelah melakukan migrasi terdapat perbedaan. Dimana setelah melakukan migrasi pendapatan migran megalami peningkatan, seperti apa yang dinyatakan oleh Todaro (dalam Damandiri 2008:23) bahwa para migran adalah mereka yang miskin, tidak memiliki tanah, tidak memiliki keahlian dan yang tidak memiliki kesempatan untuk maju di daerah asalnya, sehingga mereka melakukan migrasi untuk melepaskan diri dari belenggu kemiskinan di daerah-daerah pedesaan.

Namun jika mengacu pada UMR kabupaten Buleleng pendapatan migran asal Jawa di Kota Singaraja cenderung didominasi oleh pendapatan migran di bawah UMR. Hal ini berarti tingkat pendapatan migran dipengaruhi oleh tingkat pendidikan yang mereka pernah tempuh, sehingga menyebabkan keterampilan/skill yang mereka miliki rendah.

Berdasarkan hasil pernyataan tersebut dapat disimpulkan bahwa karakteristik para migran asal Jawa di Kota Singaraja pada masing-masing kelurahan. Dilihat dari karakteristik demografi adalah penduduk berusia 25-29 yang dominan berjenis kelamin laki-laki. Selain itu para migran yang datang ke Kota Singaraja lebih dominan migran yang sudah kawin dari pada yang belum kawin. Dari segi karakteristik sosial (pendidikan) kebanyakan para migran yang datang ke kota Singaraja hanya tamatan SMP dari pada SMA dan PT. Dilihat dari jenis pekerjaan, migran asal Jawa yang melakukan migrasi tersebut umumnya adalah mereka yang di daerah asalnya tergolong penduduk miskin, dan hidup merantau ke Kota Singaraja bekerja sebagai pedagang dan kini kehidupan para migran tersebut menjadi lebih baik dari pada tinggal di daerah asal. Namun jika dilihat dari karakteristik ekonomi (pendapatan) mengalami peningkatan setelah mereka melakukan migrasi.

\section{Faktor Pendorong dan Faktor Penarik Migran Asal Pulau Jawa Bermigrasi Ke Kota Singaraja}

Berdasarkan apa yang dikemukakan oleh Munir (dalam Mantra 2003:118) faktor penyebab migran untuk melakukan migrasi adalah adanya faktor pendorong dan penarik. Dimana faktor pendorong adalah faktor-faktor yang terdapat di daerah asal yang mendorong seseorang melakukan migrasi, sedangkan faktor penarik adalah faktor-faktor yang tedapat di daerah tujuan yang menarik seseorang melakukan migrasi ke daerah tujuan. Faktor tersebut yang menyebabkan cenderung bermigrasi ke suatu wilayah. Adapun hasilnya sebagai berikut:

\section{1) Faktor Pendorong Para Migran Asal Jawa}

Berdasarkan penilitian yang dilakukan dapat dijelaskan bahwa yang menjadi faktor pendorong para migran adalah faktor pekerjaan, sedangkan faktor pendidikan dan pernikahan relative kecil. Alasan sempitnya lapangan pekerjaan di daerah asal mendorong para migran melakukan migrasi, terdapatnya perbedaan pendapatan yang diperoleh migran, dimana minimnya pendapatan yang diperleh di daerah asal juga menjadi saah satu faktor pendorong migran usntuk melakukan migrasi ke Kota 
Singaraja guna mendapatkan pekerjaan dan pendapatan yang lebih layak dari daerah asalnya.

\section{2) Faktor Penarik Para Migran Asal Jawa}

Dapat dijelaskan bahwa apa yang dialami oleh para migran asal Pulau Jawa di daerah asal, menimbulkan ketertarikan para migran untuk bermigrasi ke Kota Singaraja. yakni pendidikan, pekerjaan, pendapata dan pernikahan/keluarga. Faktor penarik para migran asal pulau Jawa yang bermigrasi ke Kota Singaraja lebih didominasi oleh faktor pekerjaan. Hal ini dikarenakan Kota Singaraja yang secara administratif memiliki beberapa fungsi seperti pendidikan dan perdagangan. Akan tetapi pendapatan juga menjadi faktor penarik kedua setelah pekerjaan, karena pendapatan di daerah asal yang mereka dapatkan lebih sedikit dari pada daerah tujuan. Untuk faktor penarik karena alasan

pernikahan atau keluarga dan pendidikan tidak terlalu dominan. Karena sebagian besar yang melakukan migrasi hanya memiliki tujuan mendapatkan pekerjaan dan pendapatan yang lebih baik dibandingkan di daerah asalnya.

\section{SIMPULAN DAN SARAN}

\section{Simpulan}

Berdasarkan hasil dan pembahasan yang telah diuraikan dapat ditarik kesimpulan sebagai berikut (1) sebaran migran asal Pulau Jawa di Kota Singaraja tersebar pada tiga kelurahan yaitu (kelurhan Banyuasri, Kaliuntu, dan Kampung Bugis), namun jika melihat migran yang tersebar berdasarkan catatan administrasi lebih didominasi adalah catatan administrasi kelurahan Banyuasri. (2) karakteristik para migran asal Jawa di kota Singaraja adalah penduduk usia produktif yang didominasi oleh laki-laki serta migran yang berpendidikan rendah. Rendahan pendidikan menyebabkan aktivitas ekonomi yang dimasuki adalah dominan sebagai pedagang dan buruh. (3) faktor penyebab para migran asal pulau Jawa untuk meinggalkan daerahasalnya ada dua faktor yaitu faktor pendorong dan faktor penarik, faktor pendorong didominasi karena penyempitan lapangan pekerjaan dan minimnya pendapatan di daerah asal. Hal tersebut disebabkan oleh maraknya pengalihan fungsi lahan yang mengambil lahan pertanian. Sedangkan faktor penarik di daerah tujuan adalah faktor pekerjaan dan pendapatan karena semakin terbukanya kesempatan atau peluang kerja di daearah tujuan yakni (Kota Singaraja).

\section{Saran}

Saran yang dapat peniliti berikat yaitu: (1) dengan melihat sebaran migran sebaiknya pemerintah menyiapkkan lahan untuk hunian atau tempat tinggal para migran yang datang ke kota Singaraja, (2) melihat karakteristik para migran dari segi pendidikan, umumnya pendidikan migran yang rendah, diharapkan adanya suatu program dari pemerintah maupaun dinas ketenagakerjaan dalam upaya memberikan pelatihan keterampilan kerja bagi para migran yang tingkat keterampilannya rendah agar memilki modal dasar untuk mencari pekerjaan. (3) Sulitnya pekerjaan yang didapat oleh para migran baik itu daerah asal maupun di daerah tujuan tentunya membuat pemerintah setempat atau pihak terkait mampu menyediakan lapangan pekerjaan bagi para migran yang disesuaikan dengan kemampuan yang dimiliki para migran.

\section{UCAPAN TERIMAKASIH}

Penelitian ini dapat diselesaikan berkat bimbingan dari berbagai pihak. Untuk itu, pada kesempatan ini diucapkan terimakasih yang setulus-tulusnya kepada Rektor Universitas Pendidikan Ganesha, Dekan Fakultas Hukum dan Ilmu Sosial, Ketua Program Studi Pendidikan Geografi staff dosen di Program Studi Pendidikan Geografi, Pembimbing 
e- Jurnal Universitas Pendidikan Ganesha

Pendidikan Geografi

Akademik, Pembimbing 1, Pembimbing 2, Penguji 1, dan Penguji 2, Dinas-dinas Pemerintahan Kota Singaraja, Bapak Kepala Desa/Kelurahan Banyuasri, Kaliuntu, dan Kampung Bugis. Keluarga Tercinta dan Situs internet penyedia data (BPS), dan rekan-rekan mahasiswa Program Studi Pendidikan Geografi 2012.

\section{DAFTAR PUSTAKA}

Ali, Achmad. 2006. Analisis Faktor-Faktor yang Mempengaruhi Penduduk Melakukan Migrasi Internal di Indonesia. Laporan Penelitian. Tersedia pada: http://download.isi-dsp.ac.id/. Di unduh tanggal 27 desember 2016

Astawa, Made Ida Bagus dan Sarmita, I Made. 2016. Geografi Penduduk. (tidak diterbitkan). Singaraja

Badan Pusat Statistik. 2016. Kecamatan
Buleleng Dalam Anka. Buleleng. Tersedia pada: bps.go.id (di akses pada tanggal 20 Juli 2016).

BPS. Kabupaten Buleleng. 2015. Buleleng Dalam Angka. Biro Pusat Statistik Buleleng.

Mantra, Ida Bagus. 2003. Demografi Umum Edisi Kedua. Yogyakarta. Pustaka Pelajar

Kawi, Gede. 2005. Buku Ajar Geografi Penduduk. (tidak diterbitkan). Singaraja: Unversitas Pendidikan Ganesha.

Krisna Dewi, Putu Siska. 2013. Migran Urban Fringe Area Kota Singarja Serta implikasinya Terhadap Struktur Wilayah Kota Singaraja. Pendidikan Geografi, Universitas Pendidikan Ganesha. Jurnal (Hlm 5). 